\title{
Design of a solar energy harvesting system for supplying energy to an autonomous wireless sensor node
}

Diseño de un sistema energy harvesting con energía solar para proveer energía a un nodo sensor autónomo

Projeto de um sistema de colheita de energia solar para fornecer energia a um nó de sensor sem fio autônomo

\section{Mónica María Salazar Cardona ${ }^{1}$ Alejandro Marulanda Tobón ${ }^{2}$}

Received: September $16^{\text {th }}, 2020$

Accepted: December $02^{\text {nd }}, 2020$

Available: May $5^{\text {th }}, 2021$

How to cite this article: M. M. Salazar Cardona, A. Marulanda Tobón. "Design of a Solar Energy Harvesting System for The Provision Of Energy to an Autonomous Wireless Sensor Node," Revista Ingeniería Solidaria, vol. 17, no. 2, 2021. doi: https://doi.org/10.16925/2357-6014.2021.02.02

Research article. https://doi.org/10.16925/2357-6014.2021.02.02

1 Departamento de Ciencias Físicas. Escuela de Ciencias. Universidad EAFIT.

Email: mmsalazarc@eafit.edu.co

ORCID: https://orcid.org/0000-0002-1964-6659

2 Departamento de Ciencias Físicas. Escuela de Ciencias. Universidad EAFIT.

Email: amarula2@eafit.edu.co

ORCID: https://orcid.org/0000-0001-7327-9231 
2 Design Of A Solar Energy Harvesting System For Supplying Energy To An Autonomous Wireless Sensor Node

\section{Abstract}

Introduction: This paper is the product of the research "Generation of a modular electronic platform for the conformation of a WSN" developed in the EAFIT University in 2019.

Problem: Wireless Sensor Networks (WSNs) are used as a technology of information and communication (TIC) to automate processes. Their implementation is considered non-efficient because of their high cost concerning the requirement to replace node batteries.

Objective: The objective of the research is to develop more efficient solar energy harvesting systems that can guarantee an average performance of the wireless sensor node at a low cost.

Methodology: Here, we present the design and the implementation of a solar energy harvesting system that integrates a buck converter, a maximum power point tracking (MPPT) control, and a wireless sensor node. We also measure the voltage at the output of the buck converter and provide an estimate of energy autonomy in the wireless sensor node.

Results: Autonomous operation with the solar energy harvesting system was achieved for the node, sending packages each $20 \mathrm{~min}$.

Conclusion: This article presented a solar energy harvesting system with the implementation of an MPPT control.

Originality: Through this research, parameters of the MPPT control are formulated for the first time for the solar energy harvesting system design, based on the duty cycle limits.

Limitations: The availability of the devices used in the implementation of the proposed design.

Keywords: Solar panel, energy harvesting system, energy autonomy, wireless sensor nodes.

\section{Resumen}

Introducción: Este artículo es el producto de la investigación "Generación de una Plataforma electrónica modular para la conformación de una WSN" desarrollada en el 2019 en la Universidad EAFIT.

Problema: Las redes inalámbricas de sensores (WSNs) son implementadas como tecnología de la información y comunicación (TIC) para automatizar procesos. Sin embargo, su uso es considerado como poco eficiente debido al alto costo de implementación, debido al cambio de las baterías en los nodos, una vez estas se agotan.

Objetivo: El objetivo de esta investigación es desarrollar sistemas que utilicen energía solar de forma eficiente, para garantizar el desempeño de las redes inalámbricas de sensores a bajos costos.

Metodología: En este artículo se presenta el diseño y la implementación de un sistema solar compuesto de un convertidor reductor, un control de rastreo del punto de la máxima potencia (MPPT), y un nodo sensor inalámbrico. En este sistema, se realizan medidas de voltaje a la salida del convertidor reductor y se estima la autonomía de energía alcanzada en el nodo sensor.

Resultados: Se obtuvo una autonomía del nodo sensor alimentado con el sistema solar propuesto, para una comunicación inalámbrica donde se envían paquetes de datos cada $20 \mathrm{~min}$.

Conclusiones: En este artículo se presenta un sistema solar con la implementación de un control MPPT.

Originalidad: Mediante esta investigación se propone por primera vez la formulación de los parámetros del control MPPT, en términos de los límites de operación identificados para el ciclo de trabajo del convertidor.

Limitaciones: La disponibilidad de dispositivos requeridos para la implementación del diseño propuesto.

Palabras claves: Panel solar, sistema de energía solar, autonomía de energía, nodos sensores inalámbricos. 


\section{Resumo}

Introdução: Este artigo é produto da pesquisa "Geração de uma plataforma eletrônica modular para a conformação de uma RSSF" desenvolvida em 2019 na Universidade EAFIT.

Problema: Redes de sensores sem fio (RSSF) são implementadas como tecnologia de informação e comunicação (TIC) para automatizar processos. Porém, seu uso é considerado ineficiente devido ao alto custo de implantação, devido à troca das baterias nos nós, uma vez que se esgotam.

Objetivo: 0 objetivo desta pesquisa é desenvolver sistemas que utilizem a energia solar de forma eficiente, para garantir o desempenho de redes de sensores sem fio a baixo custo.

Metodologia: Este artigo apresenta o projeto e implementação de um sistema solar composto por um conversor buck, Maximum Power Point Tracking Control (MPPT) e um nó sensor wireless. Nesse sistema, as medições de tensão são feitas na saída do conversor Buck e a autonomia de energia alcançada no nó sensor é estimada.

Resultados: A autonomia do nó sensor alimentado pelo sistema solar proposto foi obtida para comunicação sem fio onde os pacotes de dados são enviados a cada $20 \mathrm{~min}$.

Conclusões: Este artigo apresenta um sistema solar com a implementação de um controle MPPT.

Originalidade: Esta pesquisa propõe pela primeira vez a formulação dos parâmetros de controle do MPPT, em termos dos limites operacionais identificados para o ciclo de trabalho do conversor.

Limitações: A disponibilidade de dispositivos necessários para a implementação do projeto proposto.

Palavras-chave: Painel solar, sistema de energia solar, autonomia energética, nós sensores sem fio.

\section{INTRODUCTION}

Wireless sensor networks (WSNs) are a set of devices connected to collect data remotely from the environment, as required by the user and they are made up of devices called nodes, which collect, process, and wirelessly communicate data through a sensor, a microcontroller, and a radio transceiver, respectively. These WSNs are present in our daily lives [1], agriculture [2], and industry [3]; however, the use of non-rechargeable storage devices as an energy source, i.e., batteries, have limited their implementation. Here, we attempt to solve this concern by designing a solar energy harvesting system (SEHS) to feed energy to wireless sensor nodes. Such an energy harvesting process from the environment is made by a solar panel, which provides the energy stored in rechargeable batteries or supercapacitors to later be used by the node [4]. Furthermore, the advantages of the proposed design are restricted to a lower cost implementation, promoting the use of renewable energy, and avoiding pollution from the non-rechargeable batteries that commercial sensor nodes implement [5], [6].

The connection of the sensor node to an energy harvesting system constitutes an autonomous wireless sensor node. This technology is currently used for the wireless communication of data, mainly because they harvest infinity sources of energy; nonetheless, this kind of energy has a not continuous behavior. For this reason, the 
4 Design Of A Solar Energy Harvesting System For Supplying Energy To An Autonomous Wireless Sensor Node

design of an energy harvesting system, for example, with solar energy, implies the implementation of specific techniques such as pulse-width modulation (PWM) and MPPT techniques [7]. Besides, these systems require a voltage adequation reached by a buck converter [8]. In the next paragraphs, our proposal will be presented. In Section 2 , the literature review of the designs and implementation of a SEHS and a sensor node is developed. Later, in Section 3, we show the proposed methodology to design and implement our autonomous sensor node, and in Section 4, we present the results and subsequent discussion. Finally, conclusions are presented in Section 5.

\section{LITERATURE REVIEW}

Existing designs of autonomous sensor nodes are used for animal tracking, air quality monitoring, and disasters [9]. For animal tracking applications, autonomous sensor nodes have carried out wireless communication every 2 hours to track the animal's position in large and rural areas. These nodes use solar panels connected to rechargeable batteries to ensure the node's continuous operation for 1 year [10]. Furthermore, in air quality monitoring applications, autonomous sensor nodes have recorded air quality parameters for 180 days, implementing a solar panel of 5W, and $12 \mathrm{~V}$ lead-acid batteries [11]. The mentioned applications are relevant to the monitoring and the subsequently study of a subject of interest, nonetheless these sensor nodes operate through solar panels and rechargeable batteries without charge controllers which result in low-efficiency operation because the solar panels themselves have efficiencies under 30\% [12],[13].

Current designs of SEHSs present the implementation of charge controllers with techniques like PWM and MPPT, which increase the efficient operation of the SEHS. These controllers can present different architectures that allow for more efficient operations according to the application to which the autonomous sensor node is directed. For instance, the controller presented in Figure 1.a implements an on-off control of the sensors, without affecting its overall functionality and implementing a supercapacitor to provide high energy spikes to the node; mostly required in the transmission process [14]. Moreover, the controller illustrated in Figure 1.b implements an MPPT control, which presents an increment of over $20 \%$ of the system efficiency compared to a PWM control [15]. Among the aforementioned, the MPPT controllers are reported to be an efficient technique to implement solar EH systems and for that reason, in the present article, we propose a design of the solar energy harvesting system with an MPPT control. Also, in the development of the SEHS design, it is necessary to determine the limits of the signal control and to calculate the values of the converter 
components [16], [17]. Other kinds of controllers in solar energy harvesting systems, i.e., the solar tracking systems, have been implemented and have been proven to provide efficient operation [18]; however, the implementation of this and other kinds of controllers are beyond our scope.

\section{A}
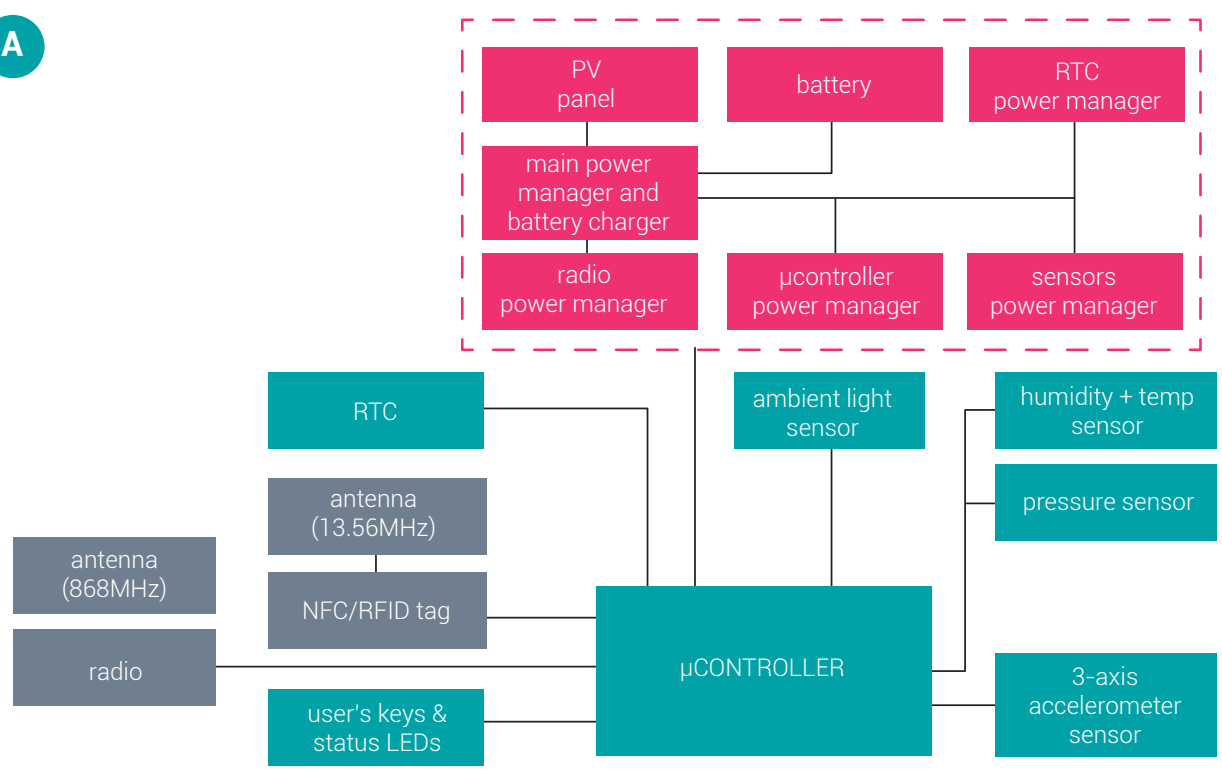

B

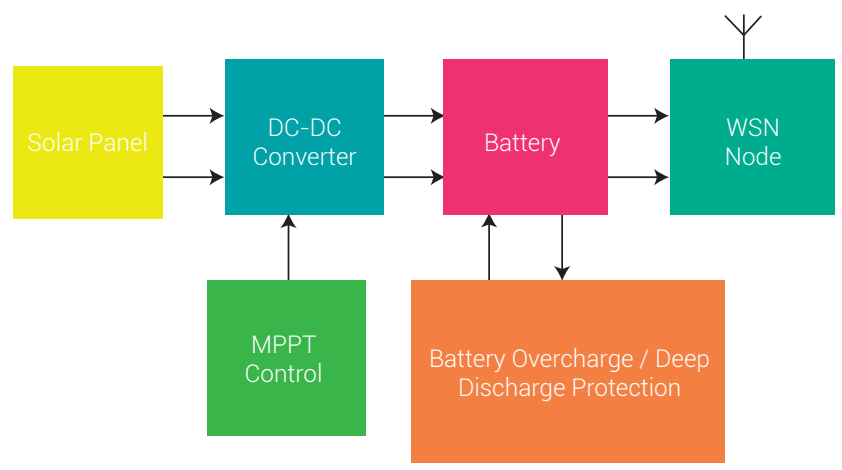

Figure 1. Architecture block diagrams of autonomous sensor nodes (a). On-off control of the sensors (b). MPPT control.

Source: Figure adapted from [8], [14].

The energy consumption problem presented in the design and the implementation of a solar energy harvesting system is a current research topic. In fact, recent designs have addressed this issue through the selection of components based on energy requirement measurements. In this scenario, the selection of components was reported according to the mathematical equation of the adjustable resistance, battery 
6 Design Of A Solar Energy Harvesting System For Supplying Energy To An Autonomous Wireless Sensor Node

performance evaluation, and current consumption [19]. Moreover, cyclical calculations of components like the inductor and the input and output capacitor of the converter were also registered [20]. Along with the latter, efficient designs of SEHS have been reported, with calculations of the current consumption of the nodes, in agriculture [21] and precision irrigation applications [22]. However, these reported designs are implemented in sensor nodes that require low energy consumption values, so they do not apply to nodes with average energy consumption.

Altogether, different SEHS design methodologies have been implemented. These methodologies are based on low energy consumption components selection [23], small components selection [14], and low energy consumption [21]. The continued importance of study in the development of new, more efficient SEHS design methodologies is evident, because of the extended presence of WSNs in many kinds of contexts, like animal tracking [10], air quality monitoring [11], and removable energies [24]. Their implementation is generally oriented to achieve the necessary power to feed the node [10] and guarantee a continued energy delivery to the node [16], [25]. Therefore, here we report the development and implementation of an SEHS design to guarantee the operation of an autonomous wireless sensor node. The proposed methodology to design such a SEHS was based on the mathematical model of a buck converter coupled with the mathematical model of a solar panel.

\section{MATERIALS AND METHODS}

The design of the SEHS for the autonomous operation of a wireless sensor node was proposed. This design integrated a solar panel of $4.5 \mathrm{~W}$, a buck converter with MPPT control, and two li-ion batteries, as suggested by recent developments of autonomous wireless sensor nodes [15]. The aforementioned three units supply energy to a wireless sensor node, designed with an Atmega328P microcontroller [26], which wirelessly transmits data every 20 minutes and has an energy consumption close to the average energy consumption of commercial sensor nodes [27], [14], [21]. Each of the solar energy harvesting components was selected based on the implementation of simulation and analytical models concerning the solar panel performance, the batteries, and the converter. The purpose of our proposed methodology was to develop an efficient design to guarantee the autonomous operation of our sensor node.

Concerning the solar panel simulation, it required experimental measurements of the open voltage, short circuit current and intermediate points of voltage and current. The purpose of the simulation was to obtain the curve characteristics of the selected solar panel. The simulation was performed following the methodology in previous 
works [28], the solar panel mathematical model presented in Equation 1 and using the Matlab/Simulink software. In Equation 1, the current $I$ is shown as a function of the voltage, $V$. Also, the resistances in series $R_{S}$ and parallel $R_{P}$ are associated with the loss produced by the leakage currents and ohmic contacts of the cell materials. These last resistances were calculated using the Newton Raphson method, as presented in [29]. Other parameters required to perform the simulation were the irradiance $G$, the reference irradiance $G_{r e f}$ the reference photocurrent $I_{p h \text {,ref }}$, the temperature coefficient $\mu_{S C}$, the difference of temperature $\Delta T$, and the diode current $I_{0}$. Figures $2 \mathrm{a}, 2 \mathrm{~b}$ and $2 \mathrm{c}$ present the block diagram implemented for the solar panel simulation, the characteristics curves of the solar panel and the measuring instruments for the Solar panel measurements.
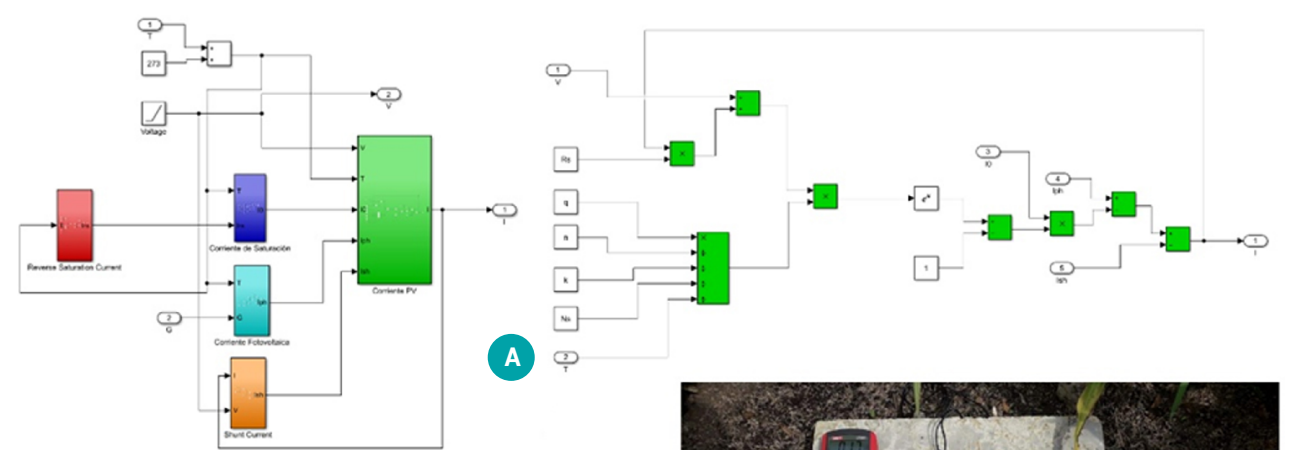

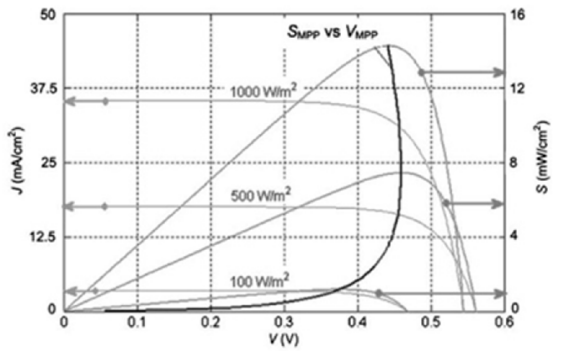

(B)

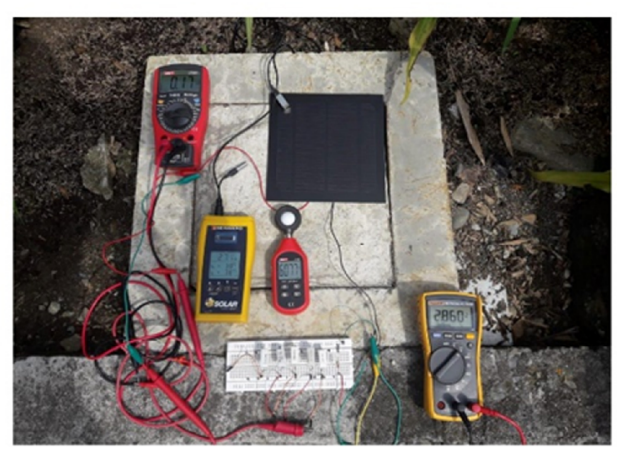

(C)

Figure 2. Solar panel measurements and data (a). Block diagram of the solar panel simulation (b). Curve characteristics of the solar panel (c). Measuring equipment. Source: Figure adapted from [16] and own work.

$$
I=\frac{G}{G_{r e f}}\left(I_{p h, r e f}+\mu_{s c} \Delta T\right)-I_{0} \mathrm{e}^{\alpha}-\frac{V+R_{s} I}{R_{p}}
$$

In addition, the implemented converter was a buck converter because the node voltage was lower than the solar panel voltage. Its design was based on an MPPT 
8 Design Of A Solar Energy Harvesting System For Supplying Energy To An Autonomous Wireless Sensor Node

control to improve the efficiency of the energy harvesting system [30]. The definition of the values of its components like the inductor, and output capacitor, were calculated with Equation 2 and 3 [31] and assuming continuous driving conditions for a $100 \mathrm{kHz}$ switching frequency and a ripple voltage $\Delta V$ of $0.5 \%$ in the output capacitor. In these equations, $f$ is the switching frequency, and $D$ is the duty cycle, which corresponds to the ratio between the converter output and input voltage.

$$
\begin{gathered}
L=\frac{R}{2 f}(1-D) \\
C=(1-D) /\left(\frac{8 L f \Delta V_{0}}{V_{0}}\right) \\
D=\frac{V_{\text {out }}}{V_{\text {in }}}
\end{gathered}
$$

In the developed design, the converter was connected to a pair of Li-ion batteries, that provide a continuous source of energy to the SEHS [32]. These batteries were chosen based on the comparison between different kinds of rechargeable batteries and their gravimetric densities, volumetric densities, charge and discharge efficiencies, nominal voltages, and self-discharge rates [33]. For this comparison, supercapacitors were not considered because, compared with the rechargeable batteries, the latter provide a more continuous operation instead of supplying high values of the current for short periods [33]. Figure 3a presents the basic blocks of the SEHS design, connected to the solar panel and the sensor node. In this figure, the buck converter performs the reduction of voltage required between the Li-ion cells, the node, and the solar panel. This reduction was requested for the implementation of the IR2104 integrated circuit to minimize the spikes of current in the inductor caused by the high frequency used to produce the switching process and, therefore, this circuit corresponds to a highly efficient technology [34]. The control signal and the implemented circuit are presented in Figure 3b and 3c. 


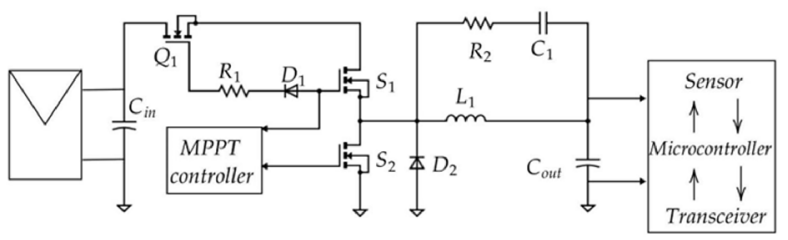

A

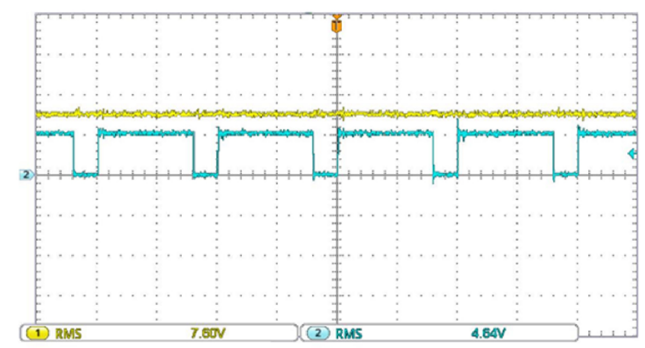

B

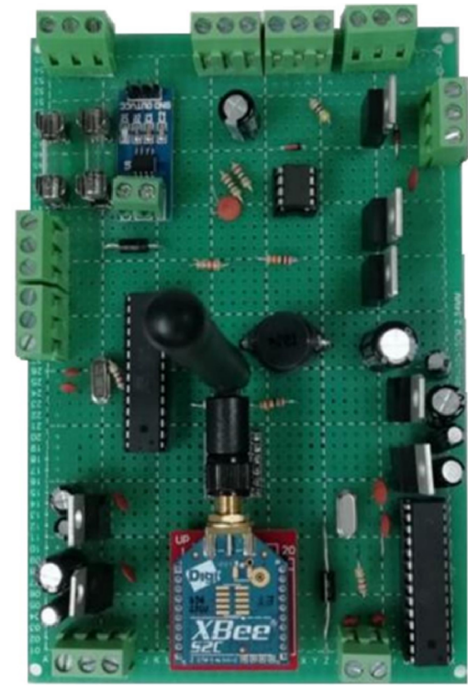

C

Figure 3. Circuit Design and implementation of the wireless autonomous sensor node (a). Circuit diagram (b). The control signal in green and the output signal of the converter in yellow (c). Autonomous sensor node board.

Source: own work.

Along with the design and implementation of the sensor node and the SEHS, the autonomous performance of our system was proved, through measurements of voltage and current consumption in the sensor node and the rechargeable batteries. These measurements were performed with 115 fluke multimeters and one TBS 1102B-EDU Tektronix oscilloscope. In the proposed set up, the SEHS was connected to the sensor node to supply energy and to a B\&K power supply to simulate the source of energy, which allowed for changes of input voltage from $10.26 \mathrm{~V}$ to $7.2 \mathrm{~V}$. The role that the charge resistance plays in the definition of the limits of the duty cycle, in our design, was done using a $15 \Omega$ load. In this scenario, the converter control signal was changed between $50 \%$ and $99 \%$. Furthermore, the proposed design was simulated, connecting the mentioned solar panel simulation and the buck converter circuit simulation in the Matlab/Simulink software. The data obtained with this simulation validated the proposed design [28], defined the required power to supply to the solar panel and estimated the maximum power points of the solar panel PV curves.

\section{RESULTS AND DISCUSSION}

The simulation of the solar panel of $4.5 \mathrm{~W}$ provided the average power for each of the curves at different irradiance, i.e., for an irradiance over 500, the simulation presents a maximum power of $1.7 \mathrm{~W}$. Figure 4 presents the other MPPs of the selected panel. 
The simulation data and the measurements of voltage and current in the solar panel presented an error of 5\%. The converter implemented the MPPT technique "perturb and observe" algorithm. The calculated values of its inductor and output capacitor were 19 of 133, respectively. The storage device used in implementing the autonomous sensor node presented an equivalent resistance that ranges from 30 to $80 \Omega$. The control sign turned off the storage device when its voltage was under $5.5 \mathrm{~V}$ and turned on over $8.5 \mathrm{~V}$.

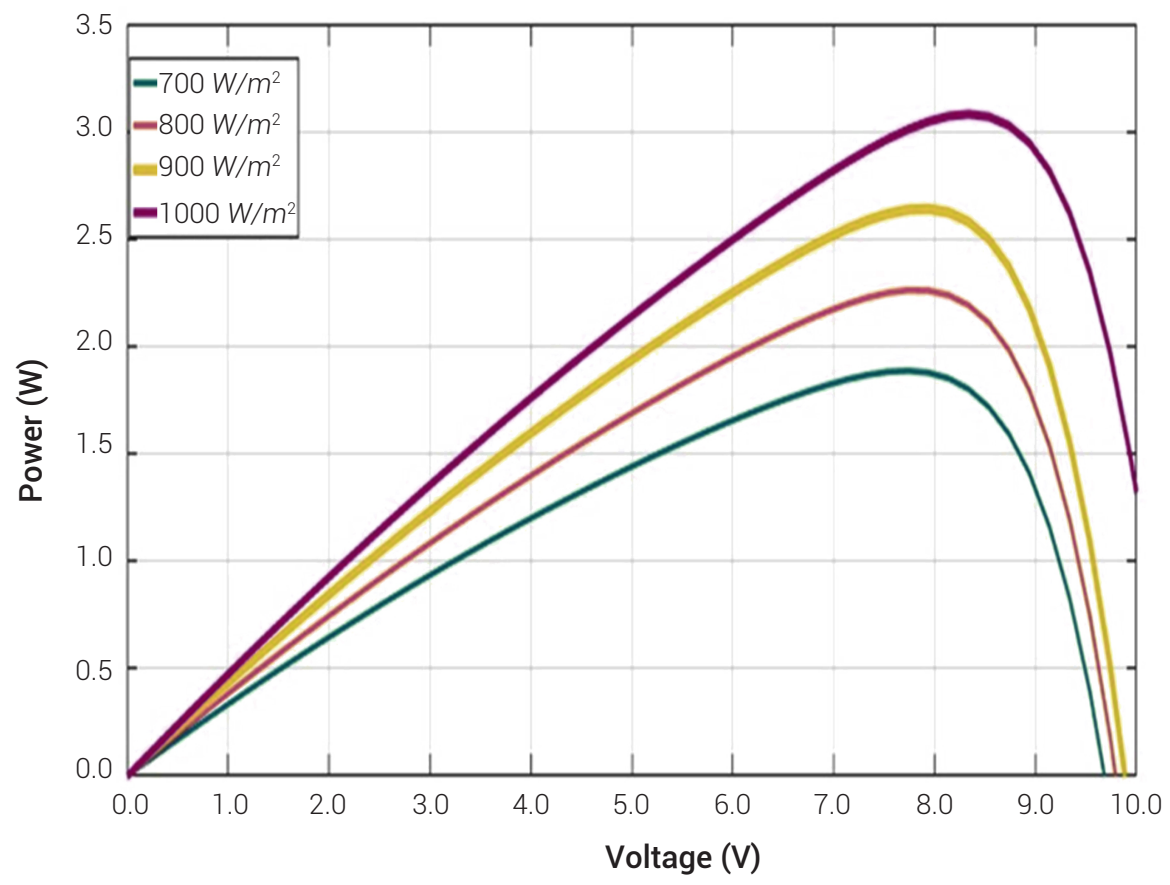

Figure 4. Solar panel PV curves from data from the simulated solar EH system. Source: own work.

The final schematic of the energy harvesting system and the designed sensor node are presented in Figure 5 and Figure 6. Along with the circuit of the converter, the design of the energy harvesting system includes a sensing circuit to measure the input and output power, a switching circuit to protect the MOSFETS of the converter from burn as a consequence of the high frequency of the MPPT signal control, and a protection circuit to isolate the solar panel and the sensor node from any reverse current or high current spikes. The former circuit described is presented in Figure 3.a. Also, the design of the sensor requires the connection of additional circuits. Figure 3.b. presents the microcontroller connection, the sensor and the transceiver to regulators that provide outputs of $5.0 \mathrm{~V}$ and 3.0, a dual bidirectional voltage-level translator for 
improving the wireless communication the connection and bypass capacitors. Figures 3.b and 3.c present the PCB design of the node and solar energy harvester system, which was developed in the free version of the program EAGLE. The presented PCB boards were chosen to have width traces of 0.025 to guarantee current transportation of $2 \mathrm{~A}$ without any damages of the designed board.

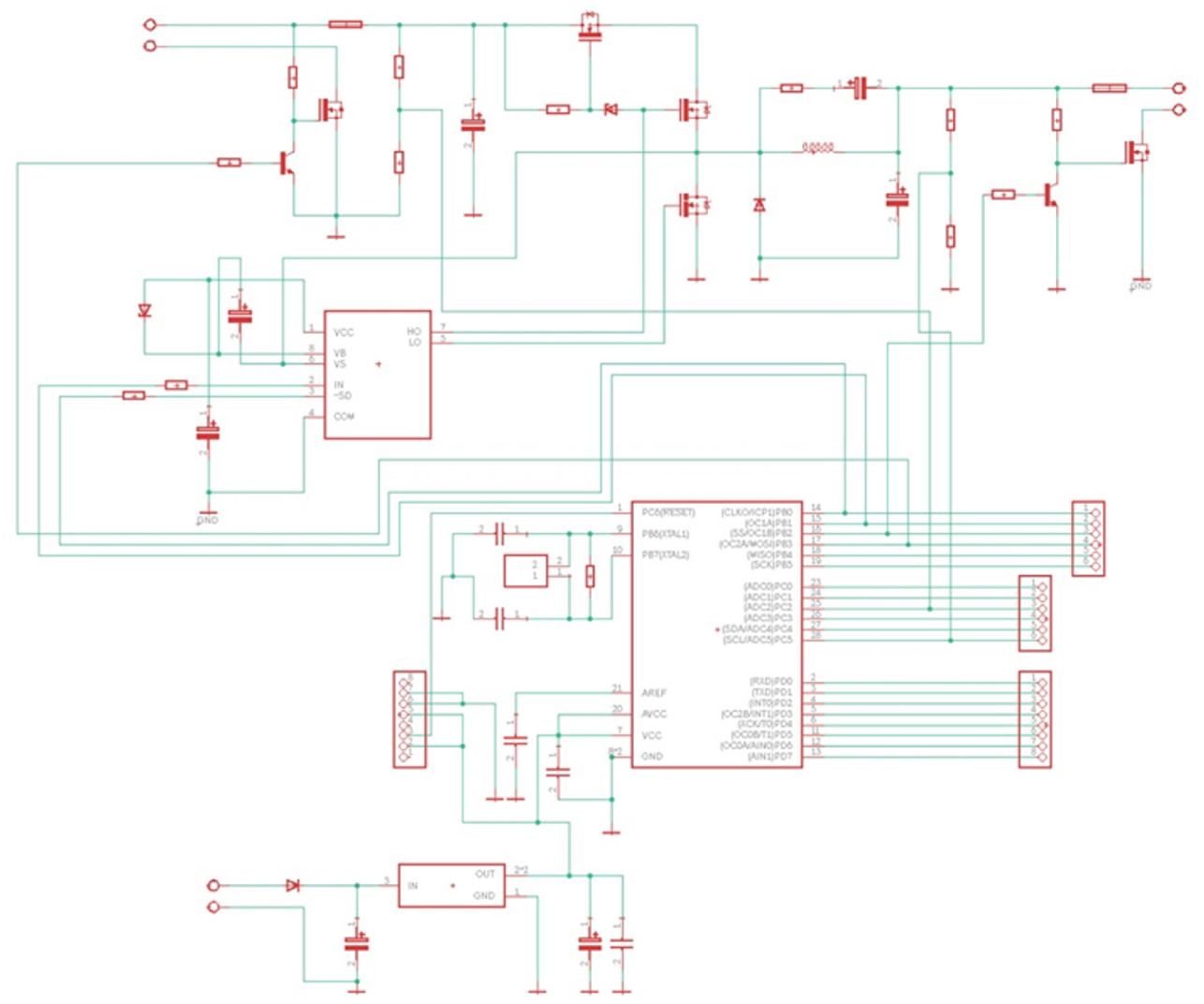

Figure 5. Schematic design of the energy harvesting system.

Source: own work. 


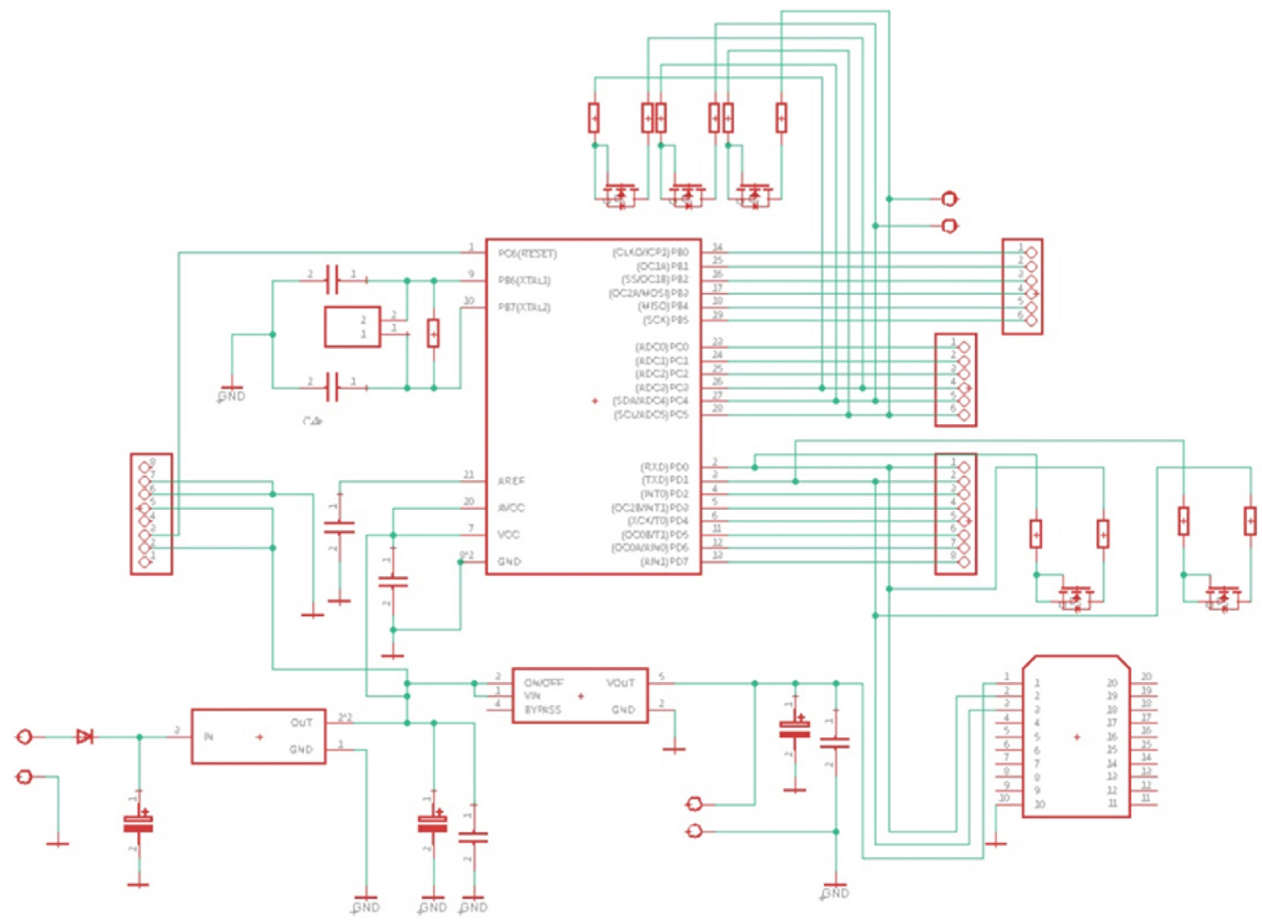

Figure 6. Schematic design of the sensor node.

Source: own work.

The efficiency achieved with the proposed design oscillated between $70 \%$ and 85\%. The variable efficiency reached by the implemented design depended on the input power, as is presented in Table 1. For a limit cycle that ranged from 0\% to 99\%, the inductor voltage presented spikes that ranged from $5 \%$ to $30 \%$ of the converter output voltage. If these spikes remain for long periods in the converter, it may damage some parts. For that reason, the limit of the duty cycle was redefined to change from $70 \%$ to $80 \%$. Figure 7 presents the discharge curve of the storage device and the discharge time of this device connected to the sensor node transmitting data packets of temperature ranging from 25 to $27^{\circ} \mathrm{C}$, wirelessly, each $5 \mathrm{sec}$ at $5 \mathrm{~V}$. This discharge time was $2.6 \mathrm{~h}$. Subsequently, the sensor node autonomous operation was verified for this node, transmitting data packages every 20 minutes.

Table 1. Measurements of voltage and current in converter.

\begin{tabular}{ccccc}
\hline $\begin{array}{c}\text { Charge } \\
\text { resistance ( }(\mathbf{\Omega})\end{array}$ & $\begin{array}{c}\text { Input voltage } \\
\text { (V) }\end{array}$ & $\begin{array}{c}\text { Input current } \\
(\mathbf{A})\end{array}$ & $\begin{array}{c}\text { Output voltage } \\
\text { (V) }\end{array}$ & $\begin{array}{c}\text { Output current } \\
\text { (A) }\end{array}$ \\
\hline 15 & 7.75 & 6.97 & 0.38 & 0.36 \\
\hline 15 & 10.0 & 7.70 & 0.12 & 0.11 \\
\hline
\end{tabular}

Source: own work. 


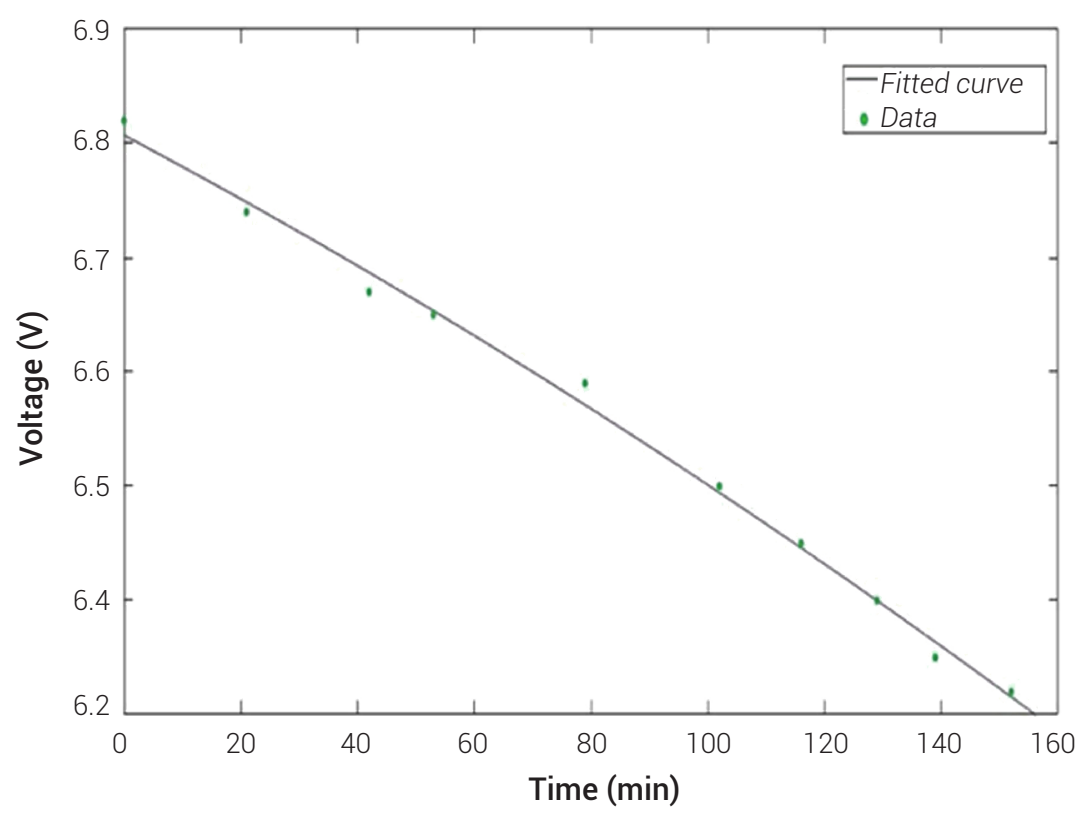

Figure 7. Measurements and fitted data from the storage device of the solar EH system. Source: own work.

With the implemented design, the autonomy of the sensor node was demonstrated, based on the solar energy harvesting system proposed. It was shown that efficiency depends on the duty cycle. Figures 8.a and 8.b present the inductor voltage signal for a converter connected to a $15 \Omega$ resistance and programmed to change its duty cycle to values up to $80 \%$. The spikes presented in Figure $3 a$ not only depend on the programmed duty cycle but also of the resistance connected to the converter, which in the present case corresponds to the sensor node and the storage device. Thus, the efficiency of the solar energy harvesting system depends not only on the duty cycle of the converter but also on the connected resistance at its output. The study of this relationship will be addressed in future research. From the commercial implementation of buck converters, it is possible to establish that these spikes are avoided by implanting complex circuits that make the process complex and exclusive [35], [36]. However, the duty cycle limits change if the connected resistance changes. Thus, future research will focus on developing an optimized mathematical model for the solar energy harvesting system design that allows us to understand the relationship between the efficiency and the resistance connected to the converter. 
A

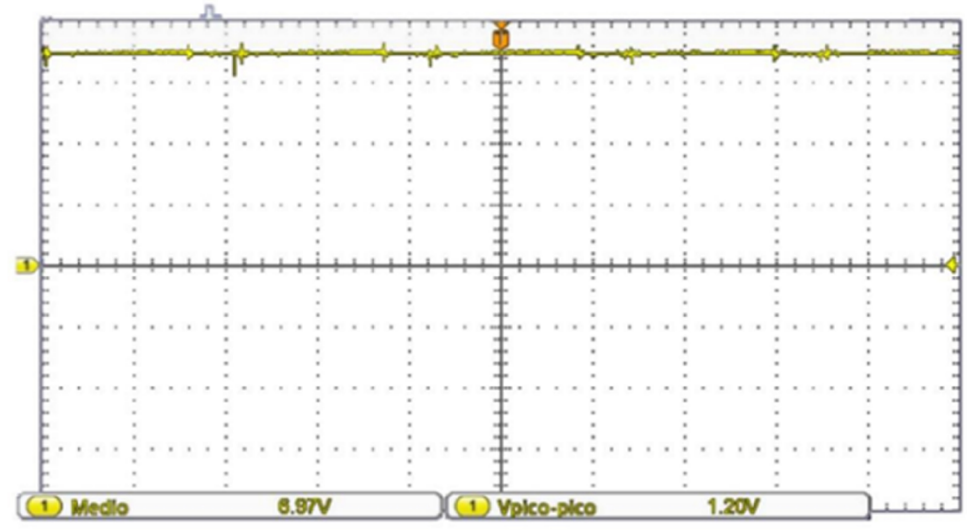

B

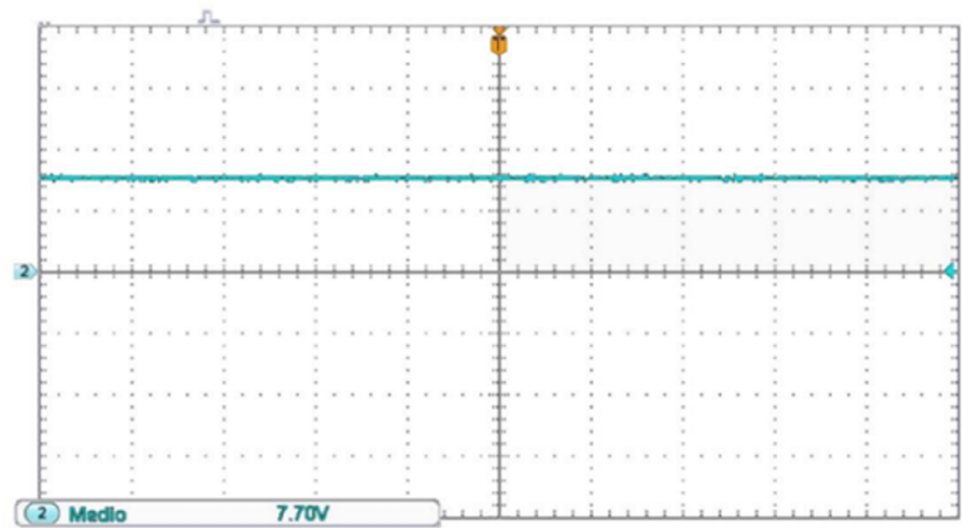

Figure 8. Output signal of the converter (a) with $D=99 \%$ (b) with $D=$ of $77 \%$. Source: own work.

\section{CONCLUSIONS}

This article presented a solar energy harvesting system with the implementation of MPPT control. The system has proved to be useful in determining the real consumption of a wireless sensor node and a pack of two cells of Li-ion batteries. The control parameters and estimated energy autonomy were defined for the proposed design. In the proposed design, the duty cycle was a topic of discussion because understanding its limits provides the required understanding of the system to propose a more efficient design of it. For this reason, future works will be directed towards improving the converter's efficiency through the optimization of the solar panel's resistance. This optimization can be achieved by developing a mathematical model of the solar $\mathrm{EH}$ system that allows us to describe the limit of the converter's duty cycle as a function of the design parameters. Also, we introduce the topic of the spikes in the signal of the inductor. These spikes present values close to $30 \%$ of the output voltage of the 
converter. This data was necessary to compare this value with the design's reported output signal and define a limit value for the spikes on the converted inductor signal [37], [38]. Based on this comparison, it was established that this value might not overcome the $22 \%$ of the output voltage to guarantee a converter's continuous transition performance. The reduction of these spikes and its relationship with the identified duty cycle limits are future challenges to investigate.

\section{REFERENCES}

[1] I. Froiz-Míguez,T.M. Fernández-Caramés, P.Fraga-LamasyL.Castedo, “Design, implementation and practical evaluation of an IoT home automation system for fog computing applications based on MQTT and ZigBee-WiFi sensor nodes," Sensors, vol. 18, no 8, p. 2660, 2018, doi:10.3390/s18082660

[2] S. A. Kumar y P. Ilango, "The impact of wireless sensor network in the field of precision agriculture: A review," Wireless Personal Communications, vol. 98, no 1, pp. 685-698, 2018, doi: https://doi.org/10.1007/s11277-017-4890-z

[3] J. Aponte-Luis, J. A. Gómez-Galán y Gómez-Bravo, "An efficient wireless sensor network for industrial monitoring and control,” Sensors, vol. 18, no 1, p. 182, 2018, doi:10.3390/s18010182

[4] M. T. Penella, J. Albesa y M. Gasulla, "Powering wireless sensor nodes: Primary batteries versus energy harvesting," In 2009 IEEE Instrumentation and Measurement Technology Conference, Singapore, pp. 1625-1630, 2009, doi:10.1186/1471-2288-12-114

[5] Crossbow Technology, Inc., "NR2 - Núcleo de Redes Sem Fio e Redes Acvanzadas," [Online]. Available: http://www.nr2.ufpr.br/ adc/documentos/iris_datasheet.pdf.

[6] Crossbow Technology, Inc., "Autexopen," [Online]. Available: http://www.openautomation. net/uploadsproductos/micaz_datasheet.pdf.

[7] M. Prauzek, J. Konecny, M. Borova y K. Janosova, "Energy harvesting sources, storage devices and system topologies for environmental wireless sensor networks: A review," Sensors, vol. 18, no 8, p. 2446, 2018, doi: https://doi.org/10.3390/s18082446

[8] R. Faraji, H. Farzanehfard y E. Adib, "Efficiency improvement of integrated synchronous buck converter using body biasing for ultra-low-voltage applications," Microelectronics Journal, vol. 63, pp. 94-103, 2017, doi: https://doi.org/10.1016/j.mejo.2017.03.007 
Design Of A Solar Energy Harvesting System For Supplying Energy To An Autonomous Wireless Sensor Node

[9] K. S. Adu-Manu, N. Adam, C. Tapparello, H. Ayatollahi y W. Heinzelman, "Energy-Harvesting Wireless Sensor Networks (EH-WSNs) A Review," ACM Transactions on Sensor Networks (TOSN), vol. 14, no 2, pp. 1-50, 2018, doi: https://doi.org/10.1145/3183338

[10] P. Zhang, C. M. Sadler, S. A. Lyon y M. Martonosi, "Hardware design experiences in ZebraNet," In Proceedings of the 2nd international conference on Embedded networked sensor systems, pp. 227-238, 2004. [Online]. Available: http://www.princeton.edu/ mrm/sensys04

[11] C. H. Wang, Y. K. Huang, X. Y. Zheng, T. S. Lin, C. L. Chuang y J. A. Jiang, "A self sustainable air quality monitoring system using WSN," In 2012 Fifth IEEE International Conference on ServiceOriented Computing and Applications (SOCA), pp. 1-6, 2012, doi: 10.1109/SOCA.2012.6449427

[12] J. B. Urbano, F. H. T. González y P. E. Perilla, "Estudio para el uso de la tecnología solar fotovoltaica," Ingeniería solidaria, vol. 6, no 10-11, pp. 69-81, 2010. [Online]. Available: https:// revistas.ucc.edu.co/index.php/in/article/view/453

[13] C. A. R. Algarín, "Sistemas híbridos: una estrategia para mejorar la eficiencia en los paneles solares," Ingeniería solidaria, vol. 7, no 13, pp. 62-67, 2011. [Online]. Available: https://revistas. ucc.edu.co/index.php/in/article/view/357

[14] C. S. Abella, S. Bonina, A. Cucuccio, S. D’Angelo, G. Giustolisi , A. D. Grasso y S. Pennisi, "Autonomous energy-efficient wireless sensor network platform for home/office automation," IEEE Sensors Journal, vol. 19, no 9, pp. 3501-3512, 2019, doi: 10.1109/JSEN.2019.2892604

[15] H. Sharma, A. Haque y Z. A. Jaffery, "Modeling and optimisation of a solar energy harvesting system for wireless sensor network nodes," Journal of Sensor and Actuator Networks, vol. 7 , no 3, p. 40, 2018, doi: https://doi.org/10.3390/jsan7030040

[16] M. T. Penella-López y M. Gasulla-Forner, Powering autonomous sensors: an integral approach with focus on solar and RF energy harvesting, Springer Science \& Business Media, 2011, doi: 10.1007/978-94-007-1573-8

[17] S. J. Chiang, H.-J. Shieh y M.-C. Chen, "Modeling and Control of PV Charger System with SEPIC Converter," IEEE Transactions on Industrial Electronics, vol. 56, no 11, pp. 4344 - 4353, 2008, doi: 10.1109/TIE.2008.2005144

[18] J. U.Castellanos, “Experimentación del hardware de control para un seguidor solar," Ingeniería solidaria, vol. 7, no 13, pp. 53-60, 2011. [Online]. Available: https://revistas.ucc.edu.co/index. php/in/article/view/356 
[19] I. Froiz-Míguez, T. M. Fernández-Caramés, P. Fraga-Lamas y L. Castedo, "Design, implementation and practical evaluation of an loT home automation system for fog computing applications based on MQTT and ZigBee-WiFi sensor nodes," Sensors, vol. 18, no 8, p. 2660, 2018, doi:10.3390/s18082660

[20] A. Frezzetti, S. Manfredi y M. Pagano, "A design approach of the solar harvesting control system for wireless sensor node," Control Engineering Practice, vol. 44, pp. 45-54, 2015, doi: https://doi.org/10.1016/j.conengprac.2015.07.004

[21] García-Lesta, D. Cabello, E. Ferro, P. López y V. M. Brea, "Wireless sensor network with perpetual motes for terrestrial snail activity monitoring," IEEE Sensor Journal, vol. 17, no 15, pp. 5008-5015, 2011, doi:10.1109/JSEN.2017.2718107

[22] R. G. Vieira, A. M. Da Cunha, L. B. Ruiz y A. P. De Camargo, "On the design of a long range WSN for Precision Irrigation,” IEEE Sensors Journal, vol. 18, no 2, pp. 773-780, 2017, doi :10.1109/ JSEN.2017.2776859

[23] F. Karray, M. W. Jmal, A. Garcia-Ortiz, M. Abid y A. M. Obeid, "A comprehensive survey on wireless sensor node hardware platforms," Computer Networks, vol. 144, pp. 89-110, 2018, doi: https://doi.org/10.1016/j.comnet.2018.05.010

[24] C. Park y P. H. Chou, "Ambimax: Autonomous energy harvesting platform for multi-supply wireless sensor nodes," In 2006 3rd annual IEEE communications society on sensor and ad hoc communications and networks, pp. 168-177, 2006, doi: 10.1109/SAHCN.2006.288421

[25] H. Shao, X. Li, C. . Y. Tsui y W. H. Ki, "A novel single-inductor dual-input dual-output DC-DC converter with PWM control for solar energy harvesting system," IEEE Transactions on Very Large Scale Integration (VLSI) Systems, vol. 22, no 8, pp. 1693-1704, 2013, doi: 10.1109/ TVLSI.2013.2278785

[26] A. Rinaldi, A. I. Natalisanto, S. Muliyono y S. Said, "Implementation of Wireless Sensor Network (WSN) to calculate air pollution index of Samarinda City," Journal of Physics: Conference Series, 2019, doi:10.1088/1742-6596/1277/1/012030

[27] A. Frezzetti, S. Manfredi y M. Pagano, "A design approach of the solar harvesting control system for wireless sensor node," Control Engineering Practice, vol. 44, pp. 45-54, 2015, https:// doi.org/10.1016/j.conengprac.2015.07.004

[28] R. Youcef y M. Fatima, "A detailed modeling of photovoltaic module using MATLAB," NRIAG Journal of Astronomy and Geophysics, vol. 3, no 1, pp. 53-61, 2014, doi:10.1016/j. nrjag.2014.04.001 
Design Of A Solar Energy Harvesting System For Supplying Energy To An Autonomous Wireless Sensor Node

[29] L. R. Reis, J. R. Camacho y D. F. Novacki, "The Newton Raphson method in the extraction of parameters of PV modules," In Proceedings of the International Conference on Renewable Energies and Power Quality (ICREPQ'17), Malaga, pp. 4-6, 2017. [Online]. Available: https:// pdfs.semanticscholar.org/f28e/c097d66471e9f4f42e9f9b9698cd55eb7587.pdf

[30] M. R. Hamid, J. Rahimi, S. Chowdhury y T. M. Sunny, "Design and Development of a Maximum Power Point Tracking (MPPT) charge controller for Photo-Voltaic (PV) power generation system," American Journal of Engineering Research, vol.5, no 5, pp. 15-22, 2016. [Online]. Available: https://www.researchgate.net/publication/318654136_Design_and_Development_of_a_ Maximum_Power_Point_Tracking_MPPT_charge_controller_for_Photo-Voltaic_PV_power_ generation_system

[31] M. H. Rashid, Power electronics handbook, Butterworth-Heinemann, 2017.

[32] Z. Gao, C. S. Chin, W. L. Woo y J. Jia, "Integrated equivalent circuit and thermal model for simulation of temperature-dependent LiFePO4 battery in actual embedded application," Energies, vol. 10, no 1, p. 85, 2017, doi: https://doi.org/10.3390/en10010085

[33] N. Kularatna, Energy storage devices for electronic systems: rechargeable batteries and supercapacitors, Academic Press., 2014, doi: https://doi.org/10.1016/C2012-0-06356-9

[34] Texas Instruments, "Texas Instruments," 2011. [Online]. Available: https://www.ti.com/lit/an/ snva533/snva533.pdf?ts=1596740038459\&ref_url=https\%253A\%252F\%252Fwww.google. com\%252F

[35] Texas Instruments, “Texas Instruments," June 2015. [Online]. Available: https://www.ti.com/ lit/ug/tiduaa0/tiduaa0.pdf?ts=1598576613382\&ref_url=https\%253A\%252F\%252Fwww. ti.com\%252Ftool\%252FTIDA-00588.

[36] Texas Instruments, "Texas Instruments," August 2014. [Online]. Available: https://www.ti.com/ lit/ug/sluuaa8a/sluuaa8a.pdf?ts=1598576565261\&ref_url=https\%253A\%252F\%252Fwww. google.com\%252F.

[37] K. Yao, Y. Qiu, M. Xu y F. C. Lee, "A novel winding-coupled buck converter for high-frequency, high-step-down DC-DC conversion," IEEE Transactions on Power Electronics, vol. 20, no 5, pp. 1017-1024, 2005, doi: 10.1109/TPEL.2005.854022

[38] S. Sharifi, M. Monfared, M. Babaei y A. Pourfaraj, "Highly Efficient Single-Phase BuckBoost Variable-Frequency AC-AC Converter With Inherent Commutation Capability," IEEE Transactions on Industrial Electronics, vol. 67, no 5, pp. 3640-3649, 2019, doi: 10.1109/ TIE.2019.2914644 